\title{
Çorum Kargı Yöresi Su ve Mera Bitki Örneklerinde Mevsimsel Flor Düzeyleri***
}

\author{
Nuri İLÇIN ${ }^{1}$, Ali ERTEKİN²* \\ ${ }^{I}$ Trabzon Limanı Veteriner Sinır Kontrol Noktasl, Trabzon, Türkiye \\ ${ }^{2}$ Ondokuz Mayıs Üniversitesi, Veteriner Fakültesi, Biyokimya Anabilim Dall, Samsun, Türkiye
}

\begin{abstract}
Özet
Bu çalışma Çorum Kargı yöresi su ve mera örneklerinde mevsimsel flor düzeylerini belirlemek amacıyla planlandı. Örnekleme alanı birinci bölge ve ikinci bölge olarak ikiye ayrıldı. Her bir bölge ova ve yayla olarak ikiye ayrıldı. Ova ve yayladan yedi alan belirlendi. İlkbahar, yaz, sonbahar ve kış mevsimlerinde ova ve yayladan 10 ml'lik polietilen tüplere 28 su ve 28 bitki örneği alındı. Çalışma için 112 su ve 112 bitki örneği alındı. Su flor analizleri yapılıncaya kadar buzdolabında $+4{ }^{\circ} \mathrm{C}$ 'de saklandı. Mera bitki örnekleri kurutuldu, öğ̈̈tüldü, analiz edilinceye kadar kuru koşullar altında oda sıcaklığında saklandı. Ovalardan alınan su örneklerinde kış mevsiminde iki bölgede ölçülen flor miktarlarındaki değişiklikler istatistiksel önem arz etti $(\mathrm{p}<0.05)$. Yaylalardan alınan su örneklerinde yapılan ölçümlerde sadece 1. bölge ile 2. bölge arasında ilkbaharda bir önem gözlendi $(\mathrm{p}<0.05)$. Ovalardan alınan bitki örneklerinde yapılan analizlerde 1. bölge ile 2. bölge arasında yaz mevsiminde bir önem saptandı $(p<0.05)$. Sonuç olarak, su ve bitki örneklerinde yapılan flor analizlerinde hesaplanan miktarlar TSE ve Sağlık Bakanlığı tarafindan belirlenen standart değerler arasında kalmıştır. Hesaplanan sonuçlar bölgede flor toksikasyonu riski olmadığını göstermektedir. Bununla beraber, bölge volkanik bir alan olduğu için kontaminasyon ihtimali göz önüne alınmalı, insan ve hayvan sağlığı açısından düzenli kontroller yapılmalıdır.
\end{abstract}

Anahtar kelimeler: Bitki, Çorum, Flor, Kargı, Su.

\section{Seasonal Fluor Levels in Water and Pasture Plant Samples of Kargı Province of Çorum}

\begin{abstract}
This study was planned to determine the seasonal fluor levels in water and pasture specimens in Çorum Karg1 region. The sampling area was divided as first region and second region. Each region was divided as the plain and highland. Seven areas were identified from plain and highland. In the spring, summer, autumn and winter seasons were taken 28 water and 28 plant samples from plain and highland with $10 \mathrm{ml}$ polyethylene tubes. 112 water and 112 plant samples were taken for the study. The water was stored in the refrigerator at $+4{ }^{\circ} \mathrm{C}$ until the fluor analysis was carried out. The pasture plant samples were dried, grinded and stored at room temperature under dry conditions until analysis. Changes in the amount of fluoride measured in two regions in winter season in water samples taken from plains were statistically significant $(\mathrm{p}<0.05)$. In the measurements made in water samples taken from highlands, only a significance was observed between the first region and the second region in the spring $(\mathrm{p}<0.05)$. In the analyses made on plant samples taken from plains, a significance was determined between the first region and the second region in the summer season $(\mathrm{p}<0.05)$. As a result, the amount of fluor quantities calculated in analyses in water and plant samples remained between the standard values determined by TSE and Ministry of Health. The calculated results show that there is no risk of fluor toxicity in the area. However, since it is a volcanic area, possibility of contamination should be taken into account and regular controls should be done in terms of human and animal health.
\end{abstract}

Keywords: Plant, Çorum, Fluor, Karg1, Water.

\footnotetext{
*Sorumlu yazar: aertekin@omu.edu.tr

**Ayn isimli doktora tezinden özetlenmiştir.

Geliş Tarihi: 20/03/2017 Kabul Tarihi: 16/06/2017
} 


\section{Giriş}

Yerleşim alanları 450 metreden 2000 metreye kadar değişen rakıma sahip Çorum Kargı ilçesi volkanik arazi özelliği gösterir [1].

Flor periyodik tabloda VII-A grubunda bulunan halojenler olarak bilinen beş kimyasal elementten biridir. Halojenlerin element olarak toksisiteleri tehlikeli düzeydedir, gaz halindeki florun solunum havasında \% 0.1 konsantrasyonda bulunması bile birkaç dakikada öldürücü etki gösterirken flor anyon iyonlarında bu etki 5-10 g alınması halinde görülür [2].

Hidroflorik asit renksiz, fumige olabilen sıvı halinde veya kuvvetli irrite edici kokulu gaz halinde bulunur. Çok düşük konsantrasyonları bile göz, burun ve boğazda yanmaya neden olur. Flor iyonu doku derinliğinde dokuları tahrib edip penetre olarak sistemik toksisite ve hücresel yıkım meydana getirir. Sistemik olarak alındığında ölüme neden olabilir [3].

İnsan kanında $0.5 \mathrm{mg} / \mathrm{L}$, kemiklerinde $\%$ 0.2-1.2 oranında flor bulunur. Ortalama 70 kiloluk bir insan vücudunda 3-6 g flor bulunur [4].

Flor normalde suda ve gıdalarda düşük konsantrasyonlarda bulunur. Taze su kaynakları genelde 0.01-0.3 ppm arasında flor içerir. Bazı bölgelerde flor düzeyi çok düşük olduğundan floru 0.7-1.2 ppm/L seviyesine getirmek için şebeke sularına flor ilaveleri yapılır [5].

Sodyum florid gibi flor içeren bileşikler diş çürümelerini önlemek için sistemik flor tedavisinde kullanılırlar [6]. Florun diş çürümelerine karşı alınması gereken miktarının $0.1 \mathrm{mg} / \mathrm{kg}$ olması gerektiği bildirilmiştir [7].

Alınan günlük flor miktarı maruz kalınan kaynaklara göre 0.46 ile 3.5-5.4 mg/gün arasında değişebilmektedir. Florun günlük maksimum güvenli tüketim dozu $10 \mathrm{mg} /$ yetişkindir [2].

Bir yetişkinin yaşı vücutta biriken flor oranını etkiler. Kemikler tarafından alınan ve vücutta biriken flor miktarı yaş ile ters orantılıdır. Genç kişilerin kemiklerinde daha fazla flor birikir [8].

WHO içme sularında bulunması gereken flor miktarını 0.5-1.5 ppm arasında [2], TSE [9] ve Sağlık Bakanlığı ise 1.5 ppm [10] düzeyinde tavsiye etmektedir.

Subtoksik dozda bir yıl kadar flor alınması kronik florozis tablosunu ortaya çıkarır [11]. Ratlarla ilgili yapılan bir çalışmada kronik florozisin karaciğer ve beyin nöronlarında apoptozis meydana getirdiği bildirilmiştir [12]. Fare ve ratlarda sodyum floridin malign kemik kanserine neden olabileceği yapılan bir çalışmada bildirilmiştir [7].

Bu çalışma Kargı ilçe merkezi ve köylerindeki içme suyu ve kaynak suları ile mera bitkilerinde mevsime bağlı flor düzeyi değişimlerini irdelemek amacıyla planlanmıştır.

\section{Materyal ve Metot}

\section{1. Örneklerin Toplandığı Bölgeler}

Örnekleri topladığımız bölge (Çorum-Kargı bölgesi) yaklaşık 1277 km² $^{2}$ lik bir alanı kapsamaktadır. Bu alan 1. bölge ve 2. bölge olmak üzere ikiye bölündü. Her bir bölge de kendi içinde ova ve yayla olarak ikiye ayrıldı. Ova ve yayladan örnekleme yapılacak yerler olarak yedi alan belirlendi. 1. bölgenin ova örnekleri Kargı merkez, Halılar, Oğuz, Beygircioğlu, Dereköy, Pelitçik ve Avşar köyü alanından, 1. bölge yayla örnekleri Başköy, Hacıveli, Akçataş, Gölet, Alioğlu, Kargı yaylası ve Yağcılar köyü civarlarından alınan örneklerden oluştu. 2. bölge ova örnekleri Karaboya, Karapürçek, Gökçedoğan, Maksutlu, Köprübaş1, Örencik ve Saraycık köyü alanından, 2. bölge yayla örnekleri Akkaya köyü, Gökçedoğan yaylası, Dereköy yaylası, Cihadiye, Abdullah, Güney köyü ve Günyazı köyü civarlarından alınan örneklerden oluştu. Kargı dağlık bir alan olduğu için örneklerin alınacağı bölgeler insan ve hayvan popülasyonuna, hayvanların daha yoğun otladığı meralara ve yükseltilerine göre belirlendi.

\subsection{Su ve Bitki Örneklerinin Toplanması ve Saklanması}

Sonbahar (Ekim 2015), Kış (Ocak 2016), İlkbahar (Nisan 2016) ve Yaz (Temmuz 2016) mevsimlerinde iki bölgeye ayrılmış olan ova ve yayladan $10 \mathrm{ml}$ 'lik polietilen tüplere her mevsim için 28 su ve 28 bitki örneği alındı. Tüm mevsimler toplamında 112 su ve 112 bitki örneği alındı. Örnekler Kargı merkezde şebeke suyundan diğer köylerde kaynak sularından toplandı. Su örnekleri flor analizleri yapılıncaya kadar 
buzdolabında $+4{ }^{0} \mathrm{C}$ 'de saklandı. Mera bitki örnekleri kurutulduktan sonra elektrikli el değirmeninde her bir örnek $30 \mathrm{~g}$ olacak şekilde ögütüldü, plastik poşetlerde analizleri yapılıncaya kadar kuru ortamda oda sıcaklığında saklandı. Mera bitki örnekleri bitki çeşiti ayrımı yapılmadan hayvanların yoğun olarak otladığı yerlerden alınd.

\subsection{Metot}

Flor elektrodunun kalibrasyonu için kullanılan 0.1 M NaF (Orion 940906) solüsyonu Thermo Scientific firmasından temin edildi. Kalibrasyonda 190, 19, 1.9 ve 0.19 ppm'lik NaF standartları kullanıldı. 190 ppm'lik standart için $0.1 \mathrm{M} \mathrm{NaF}$ 'den $10 \mathrm{ml}$ alındı, 19 ppm'lik standart için $1 \mathrm{ml}, 1.9$ ppm'lik standart için $0.1 \mathrm{ml}$ alındı, 0.19 ppm'lik standart için $0.01 \mathrm{ml}$ alındı ve hepsi distile su ile $100 \mathrm{ml}$ 'ye tamamlandı [13].

10 ml'lik polietilen tüplere alınan standart örnekleri vorteksle üç dakika boyunca karıştırıldı. Hemen sonrasinda Orion 720A model potansiometrede her bir standart ikişer defa okundu ve flor elektrodunun kalibrasyonu yapıldı. Tüm çalışma süresince elektrodun kalibrasyonu ölçüm öncesinde tekrar edildi [14].

\subsection{Standart Eğrinin Oluşturulması}

0.1 M NaF'den $5.26 \mathrm{ml}$ alındı distile su ile $100 \mathrm{ml}$ 'ye tamamlandı, böylece $100 \mathrm{ml} 100$ ppm'lik stok flor standart solüsyonu hazırlanmış oldu.

100 ppm'lik flor solüsyonundan stok çözeltiler hazırlandı. Buna göre 0.1 ppm'lik stok flor solüsyonu hazırlamak için 100 ppm'lik flor solüsyonundan $0.2 \mathrm{ml}$ alındı, üzerine $50 \mathrm{ml}$ TISAB II (Total Ionic Strength Adjustment Buffer, Orion, 940909, Thermo Scientific firmasından temin edildi.) ilave edildi ve distile su ile $100 \mathrm{ml}$ ' ye tamamland1. $0.2,0.3,0.4,0.5,1,1.5,2.0,5.0$ ve $10.0 \mathrm{ppm}$ ' lik stok örnekleri de benzer şekilde hazırlandı. Stoklar Kahraman ve ark., (14)'larının bildirdiği metoda göre çalışıldı, her bir örnek için ikişer defa okuma yapıldı. Veriler excel'de işlenerek standart eğri ve formülü oluşturuldu (Şekil 1). Tüm hesaplamalar standart eğriden oluşturulan formüle göre yapıldı.

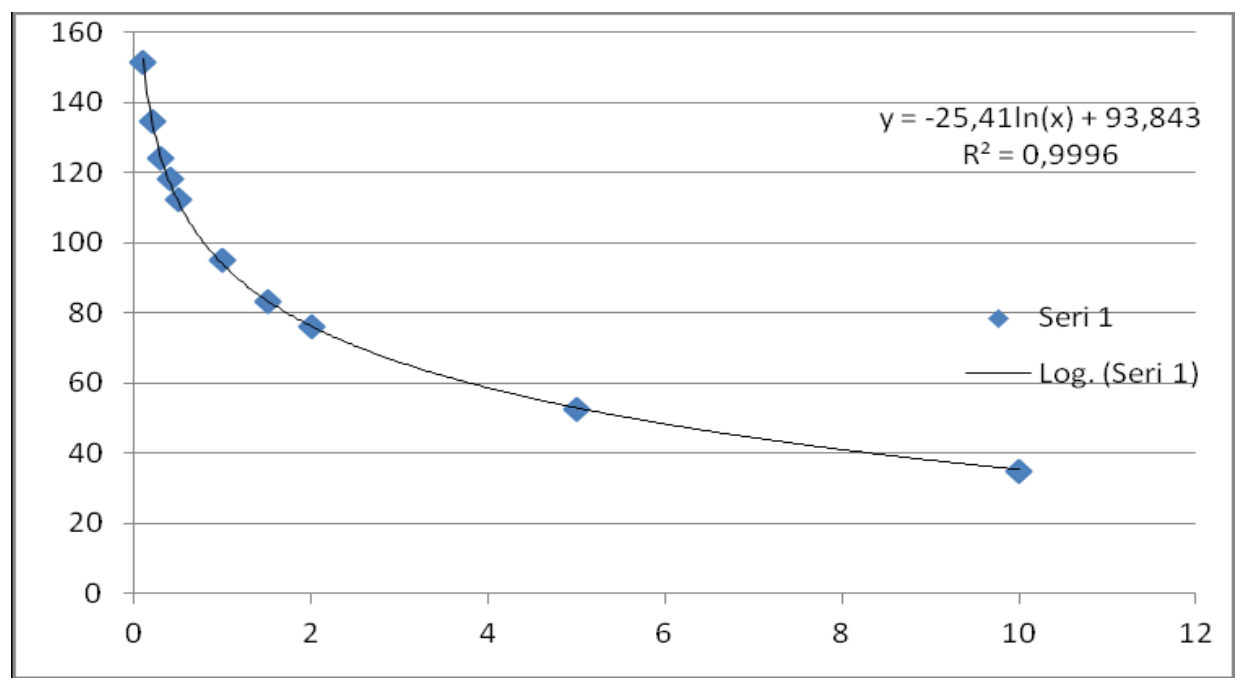

Şekil 1. Flor stok solüsyonundan çıkartılan standart eğri

\subsection{Su Flor Analizleri}

$+4{ }^{\circ} \mathrm{C}$ 'de muhafaza edilen su örnekleri 5'şer ml'lik polietilen tüplere alındı. Örnekler Kahraman ve ark. [14]'larının bildirdiği metoda göre çalışıldı.

\subsection{Bitki Flor Analizleri}

Kurutulmuş ve iyice öğütülmüş bitki örneğindeki flor ölçümü Eyde [15]'nin metoduna göre yapıldı. 


\section{7. İstatistiksel Analiz}

İstatistiksel analizler için SPSS 21.0 paket programı Independent-T Testi kullanıldı. Veriler ortalama \pm standart sapma olarak hesapland.

\section{Bulgular ve Tartışma}

Tablo 1. Çorum Kargı bölgesi ova su ve bitki örnekleri flor düzeyleri

\begin{tabular}{|c|c|c|c|c|c|c|c|c|c|}
\hline \multirow[t]{2}{*}{ Bölgeler } & \multirow[t]{2}{*}{$\mathrm{n}$} & \multicolumn{2}{|c|}{ İlkbahar } & \multicolumn{2}{|c|}{ Yaz } & \multicolumn{2}{|c|}{ Sonbahar } & \multicolumn{2}{|c|}{$\mathrm{K}_{1}$ ş } \\
\hline & & $\mathrm{Su}$ & Bitki & $\mathrm{Su}$ & Bitki & $\mathrm{Su}$ & Bitki & $\mathrm{Su}$ & Bitki \\
\hline & & 0.335 & 0.422 & 0.411 & 0.332 & 0.205 & 0.500 & 0.073 & 0.397 \\
\hline \multirow[t]{2}{*}{ 1. Bölge } & 7 & \pm & \pm & \pm & \pm & \pm & \pm & \pm & \pm \\
\hline & & 0.026 & 0.014 & 0.051 & $0.028^{\mathrm{a}}$ & 0.022 & 0.020 & $0.010^{\mathrm{a}}$ & 0.015 \\
\hline \multirow[t]{3}{*}{ 2. Bölge } & 7 & 0.302 & 0.482 & 0.372 & 0.435 & 0.202 & 0.451 & 0.038 & 0.431 \\
\hline & & \pm & \pm & \pm & \pm & \pm & \pm & \pm & \pm \\
\hline & & 0.046 & 0.025 & 0.033 & $0.028^{\mathrm{a}}$ & 0.018 & 0.065 & $0.009^{a}$ & 0.027 \\
\hline
\end{tabular}

Flor düzeyleri ppm olarak hesaplanmıştır. Veriler ortalama \pm standart sapma olarak hesaplandı. 1. ve 2. bölge mevsimler arası istatistik analizleri $(\mathrm{a} p<0.05)$.

\subsection{Ova Su ve Bitki Verileri İstatik Analizleri}

1. bölge su örneklerinde ilkbahar yazda önem bulunmadı, ilkbahar ve sonbaharda $(\mathrm{p}<0.01)$, ilkbahar ve kışta $(p<0.001)$, yaz ve sonbaharda $(p<0.05)$, yaz ve kışta $(p<0.01)$, sonbahar ve kışta $(p<0.001)$ istatistik önem bulundu. 1. bölge bitki örneklerinde ilkbahar yazda $(\mathrm{p}<0.05)$ ve ilkbahar sonbaharda $(\mathrm{p}<0.01)$ anlam gözlendi, ilkbahar kışta bir anlam gözlenmedi. Yaz sonbahar $(p<0.01)$ ve sonbahar kışta $(p<0.001)$ değişimler anlamlı iken yaz kış mevsiminde bir anlam saptanmadı.

2. bölge su flor miktarlarında ilkbahar yaz ve ilkbahar sonbaharda $(p<0.01)$, ilkbahar ve kışta $(p<0.001)$, yaz sonbahar, yaz kış ve sonbahar kışta $(\mathrm{p}<0.001)$ istatistik önem bulundu, 2. bölge bitki flor düzeylerinde istatistik bir önem bulunamad.

Tablo 2. Çorum Kargı bölgesi yayla su ve bitki örnekleri flor düzeyleri

\begin{tabular}{|c|c|c|c|c|c|c|c|c|c|}
\hline \multirow[t]{2}{*}{ Bölgeler } & \multirow[t]{2}{*}{$\mathrm{n}$} & \multicolumn{2}{|c|}{ İlkbahar } & \multicolumn{2}{|c|}{ Yaz } & \multicolumn{2}{|c|}{ Sonbahar } & \multicolumn{2}{|c|}{ Kış } \\
\hline & & $\mathrm{Su}$ & Bitki & $\mathrm{Su}$ & Bitki & $\mathrm{Su}$ & Bitki & $\mathrm{Su}$ & Bitki \\
\hline & & 0.394 & 0.454 & 0.405 & 0.427 & 0.214 & 0.474 & 0.068 & 0.430 \\
\hline \multirow[t]{2}{*}{ 1. Bölge } & 7 & \pm & \pm & \pm & \pm & \pm & \pm & \pm & \pm \\
\hline & & $0.020^{\mathrm{a}}$ & 0.024 & 0.020 & 0.010 & 0.010 & 0.030 & 0.004 & 0.010 \\
\hline \multirow[t]{3}{*}{ 2. Bölge } & 7 & 0.324 & 0.472 & 0.387 & 0.435 & 0.200 & 0.521 & 0.052 & 0.457 \\
\hline & & \pm & \pm & \pm & \pm & \pm & \pm & \pm & \pm \\
\hline & & $0.014^{\mathrm{a}}$ & 0.021 & 0.023 & 0.017 & 0.020 & 0.042 & 0.016 & 0.024 \\
\hline
\end{tabular}

Flor düzeyleri ppm olarak hesaplanmıştır. Veriler ortalama \pm standart sapma olarak hesaplandı. 1. ve 2. bölge mevsimler arası istatistik analizleri $(\mathrm{a} p<0.05)$. 


\subsection{Yayla Su ve Bitki Sonuçları İstatistik Analizleri}

1. bölge su örneklerinde ilkbahar yazdaki değişimler istatistik bir anlam ifade etmezken ilkbahar sonbahar ve ilkbahar kışta $(p<0.001)$ bir önem gözlendi. Yaz sonbahar, yaz kış ve sonbahar kışta $p<0.001$ düzeyinde bir anlam bulundu. 1. bölge bitki örneklerinde istatistik bir önem gözlenmedi.

2. bölge su örneklerinde ilkbahar yaz ve ilkbahar sonbaharda $(\mathrm{p}<0.01)$, ilkbahar kışta $(\mathrm{p}<0.001)$, yaz sonbaharda $(\mathrm{p}<0.001)$ ve yaz kışta $\mathrm{p}<0.01$ kadar anlam belirlendi. 2 . bölge bitki örneklerinde ise ilkbahar yaz $(\mathrm{p}<0.05)$ hariç diğer tüm ölçümler istatistik açıdan bir anlam ifade etmedi.

\subsection{1. ve 2. Bölge Mevsimler Arası Su Örnekleri İstatistik Analizleri}

1. bölge ilkbahar 2. bölge ilkbahar, 1. bölge yaz 2. bölge yaz, 1. bölge sonbahar 2. bölge sonbahar mevsimleri arasında ova su örneklerinde istatistik açıdan bir önem gözlenmedi. Sadece kış mevsiminde $\mathrm{p}<0.05$ kadar bir önem gözlendi.

Yaylalardan alınan su örneklerinde yapılan ölçümlerde sadece 1. bölge ile 2. bölge ilkbahar mevsimlerinde $\mathrm{p}<0.05$ kadar bir önem saptandı diğer mevsimler istatistik bir anlam ifade etmedi.

\subsection{1. ve 2. Bölge Mevsimler Arası Bitki Örnekleri İstatistik Analizleri}

1. ve 2. bölge ova bitki örneklerinde 1. bölge yaz 2. bölge yaz mevsimleri $(\mathrm{p}<0.05)$ hariç diğer mevsimlerde istatistik bir önem bulunmad. Yayla bitki örnekleri tüm mevsimlerde istatistik bir önem göstermedi.

Kalsiyum florür, kalsiyum florofosfat, sodyum floroborat, aliminyum florür, sodyum florür gibi flor bileşikleri atmosferde, bitkisel ve hayvansal dokularda, su ve toprakta çeşitli yoğunluklarda bulunur. Volkanik bölgelerdeki su kaynakları yüksek oranda flor içerir. Flor endüstriyel sanayi bölgeleri ve kömür madenlerinin bulunduğu yerlerde de yoğun miklarlarda bulunur [11].

Türkiye'de dahil olmak üzere pek çok ülkede içme suyuyla bağlantılı olarak endemik kronik florozis vakaları görülmektedir [16]. Güney Afrika, Sudan, Etiyopya, Uganda, Kenya, Tanzanya endemik florozisin önemli sağlık problemi olduğu ülkelerdendir. Türkiye'de ise sıklıkla Isparta, Ağrı (Doğubayazıt), Kırşehir (Kaman ve Kırkpınar), Nevşehir (Ürgüp, Avanos ve Hacıbektaş), Kayseri (İncesu), Eskişehir (Beylikahır) ve Uşak (Eşme)'ta görülür [17].

Toprak kompozisyonu volkanik arazi yapısı, fosfat taşları, flor rezervleri, tarımda kullanılan fosfatlı gübreler, insektisitler ve flor içeren antelmentikler de çevresel florozise sebep olan faktörlerden sayılabilir [18].

İnsanlar için günlük 1.5-4.0 mg flor alınması önerilmektedir. Bu miktar gıdalar, diş ve ağız bakım ürünleriyle alınabildiği gibi içme suyu ile de alınabilir [19].

Kronik florozisin makroskobik klinik belirtileri 10 ppm'den fazla flor içeren suların uzun süre içilmesi halinde ortaya çıkar. Bu belirtiler dişlerde lekeler, aşınma yumuşama oynama düşme, horizontal sarı kahverengi çizgiler, tekrarlayan topallıklar, artroz, ömür kısalması, deride sertleşme, kıllarda kabalaşma, uterus kanaması, gebelik ve doğum bozuklukları, kollajen parçalanması, nörolojik dejenerasyonlar, mental gerilik, kromozom değişiklikleri ve inatçı ishal olarak sıralanabilir. Bu semptomların seyri maruz kalınan flor miktarına, sindirim süresine, flor alımında zamana ve mevsime bağlı dalgalanmalara, alınan flor bileşiğinin kimyasal yapısına, eriyebilirliğine, canlının yaşına ve beslenme durumuna ve diğer biyolojik bireysel farklılıklara bağlı olarak değişir [20].

Vücuda alınan flor, karaciger, böbrek üstü bezi, kalp kası ve sinir dokuları üzerine de dejeneratif etki yapmakta ayrıca tiroit bezi yetersizlikleri ile anemi belirtilerinin de ortaya çıkmasına sebep olabilmektedir [21]. Endemik florozisli alanlarda yapılan bir çalışmada insanların aldığı toplam florun \%70'inin gıda ve çay kökenli olduğu bildirilmiştir [22]. Sulardaki florun insan sağlığı üzerindeki etkisi alınan flor miktarına göre değişmektedir. 1-3 mg/L florun dişlerde solma, beneklenme ve çürüme, 3-4 mg/L florun kemik ve eklemlerde sertlik ve kırılganlık, 4-6 mg/L ve üzeri florun ise diz ve kalçalarda deformite, felç ve topallık meydana getirdiği bildirilmiştir [23]. 
Çorum Kargı ovaları su örneklerinde, 1. bölgede en yüksek flor düzeyi yaz mevsiminde $(0.411 \pm 0.051 \mathrm{ppm})$, en düşük flor düzeyi kış mevsiminde $(0.073 \pm 0.010 \mathrm{ppm})$ gözlendi. 2. bölge en yüksek miktar ilkbaharda $(0.372 \pm 0.033 \mathrm{ppm})$ en düşük miktar ise k1ş mevsiminde $(0.038 \pm 0.009 \mathrm{ppm})$ saptandı.

Kargı yöresi 1. bölge yayla en yüksek flor düzeyi yaz mevsiminde $(0.405 \pm 0.020 \mathrm{ppm})$, en düşük flor düzeyi kış mevsiminde $(0.068 \pm 0.004 \mathrm{ppm}), 2$. bölge en yüksek ve en düşük flor miktarı yaz ve kışta (sırasıyla $0.387 \pm 0.023,0.052 \pm 0.016$ ppm) ölçüldü.

Bölgelerden alınan su örneklerinde hesaplanan miktarlar TSE ve Sağlık Bakanlığı tarafından belirlenen sınır değerler arasında kalmıştır. Tespit edilen bu sonuçlar bölgede flor toksikasyonu riskinin şu an için olmadığını göstermektedir.

Tuluk ve ark. [24]'ları Erzurum şehir merkezi içme sularında yaptıkları bir çalışmada, şebeke suyu flor düzeylerini 0.12-0.19 mg/L olarak tespit etmişlerdir. Bulmuş oldukları bu değerler Kargı (kış mevsimi hariç) flor miktarlarından daha düşük düzeydedir.

İstanbul (Anadolu yakası) halkının içme ve kullanma suyu olarak kullandıklan 10 bölgeden alınan kaynak sularında bir yıllık periyotta ölçülen flor düzeyleri 0.01-0.46 mg/L seviyelerinde bulunmuştur. Bizim çalışmamızda sonuçlar 0.02-0.41 ppm arasında değişmektedir, geneline baktığımızda Kargı flor düzeyleri ile benzerlik göstemektedir [25].

Yine benzer şekilde Van Erciş’te 18 bölgeden alınan içme sularında flor düzeyleri $0.58 \pm 0.07 \mathrm{mg} / \mathrm{L}$ aralığında tespit edilmiştir. Bölgedeki flor düzeyleri Kargı bölgesinden daha yüksek çıkmıştır [26].

Yılmaz ve ark. [27] 2014 yılı Düzce ili Konuralp beldesi içme sularında yaptıkları bir çalışmada flor düzeylerini $0.1 \mathrm{mg} / \mathrm{L}, 2011$ yılı Isparta ili içme sularında yapılan bir başka çalışmada [28] flor düzeyleri 0.13-1.70mg/L arasında, yine 2011'de yapılan bir çalışmada [14] Bitlis ili merkez ve ilçelerinde flor düzeyleri 0.02-0.77 ppm aralığında saptanmıştır. Çalışmamızdaki sonuçlarla karşılaştırdığımızda Düzce ili flor miktarları daha düşük, Isparta ili tamamında Bitlis ili ise genelinde daha yüksek oranlarda bulunmuştur.

Florun sodyum florid formunda günlük olarak $0.5-1.7 \mathrm{mg} / \mathrm{kg}$ kadar alınması büyümekte olan hayvanlarda genel sağlığı etkilemeksizin diş lezyonları meydana getirebilmektedir. Yetişkin hayvanlarda ise bu miktarın iki katı kadar bile olsa hastalık belirtileri görülmemektedir. Florun plazmada kalsiyumu kalsiyum florid şeklinde bağlaması hayvanlarda tetani, aşırı duyarlılık gibi sinirsel semptomların ortaya çıkmasına neden olmaktadır. Ayrıca kanda pıhtılaşma bozukluğu ortaya çıkmakta ve kısa sürede ölüm şekillenmektedir. Flor gazlarının inhalasyonu, şiddetli bronkospazm veya akciğer ödemiyle sonuçlanabilmektedir [29]. Ayrıca, flor reabsorbsiyonu böbrek tübüler sıvı pH'sı ile de ilişkilidir. Asidozun florid retensiyonuna, alkalozun ise florid reabsorbsiyonunun azalmasına neden olduğu bildirilmektedir [30]. Florun sodyum florid formu ameloblastlar, odontoblastlar, sementoblastlar, sementositler, osteoblastlar ve osteositler için toksiktir [31]. Diş florozisi, ameloblastlarda mine formasyonunun zarar görmesi sonucu ortaya çıkan bir tür mine hipoplazisidir [32].

Uzun süre flor alınmasına bağlı olarak iskelet yapısında artan flor, hayvanda görülebilecek olası yan etkilere ve kemik morfolojisindeki değişikliklere kısa sürede neden olmayabilir. Bazı otoburlarda, bir veya daha uzun yıllar her gün toksik dozda flor almalarına rağmen, genel toksik etkiler göstermeyerek gizli bir seyir izleyebilmektedir. Çünkü flor iskelette yavaş yavaş birikmekte ve giderek artmakta, ancak doyum noktasına ulaşıp immobilizasyon kapasitesini aştıktan sonra serbest hale geçerek genel toksik etkiler ortaya çıkarmaktadır [33].

Akut flor zehirlenmelerinde damar içi kalsiyum infüzyonları ile iyi sonuçlar elde edilebildiği bildirilmiştir. Yapılan bir çalışmada 38 hafta süreyle $4 \mathrm{ppm} /$ gün sodyum florid verilerek florozis oluşturulan Tuj irkı koyunlarda dişlerde enine çizgili lekeler ve canlı ağırlık azalışı olduğu görülmüştür [34].

Kargı yöresi ova bitki örneklerinde en yüksek flor düzeyi 1. bölgede sonbaharda $(0.500 \pm 0.020 \mathrm{ppm})$, en düşük düzey yazda $(0.332 \pm 0.028 \mathrm{ppm}), 2$. bölge en yüksek flor seviyesi ilkbaharda $(0.482 \pm 0.025 \mathrm{ppm})$, en düşük flor seviyesi kışta $(0.431 \pm 0.027$ ppm) ölçüldü. 
Yayla mera bitki örneklerinde 1. ve 2. bölge en yüksek flor miktarı sonbaharda (sırasıyla $0.474 \pm 0.030$, $0.521 \pm 0.042 \mathrm{ppm}$ ), her iki bölgede en düşük miktar yazda (sırasıyla $0.427 \pm 0.010,0.435 \pm 0.017 \mathrm{ppm}$ ) saptand1.

Ova ve yayla su örneklerinde olduğu gibi bitki örneklerinde de hesaplanan flor miktarları TSE ve Sağlık Bakanlığı tarafından belirlenen sınır değerler arasında kalmıştır.

\section{Sonuç ve Öneriler}

Sonuç olarak, hem su ve hem de bitki örneklerinde ölçülen flor miktarları TSE ve Sağlık Bakanlığı tarafından belirtilen sınır değerleri arasında kalmıştır. Tespit edilen bu sonuçlar bölgede flor toksikasyonu riskinin şu an için mevcut olmadığını göstermektedir. Bununla beraber bölgenin volkanik özellik göstermesi nedeniyle yetkili kurumlarca düzenli olarak flor ölçümleri yapılmasının uygun olacağı kanaatindeyiz.

\section{Teşekkür}

Bu araştırma VET-1904.15.011 no'lu proje ile Ondokuz Mayıs Üniversitesi Bilimsel Araştırma Projeleri Komisyon Başkanlığı'nca desteklenmiştir.

\section{Kaynaklar}

1. Tüysüz O. 1985. Kargı Masifi ve Dolayındaki Tektonik Birliklerin Ayırdı ve Araştırılması. İstanbul Üniversitesi, Fen Bilimleri Enstitüsü Doktora Tezi, Türkiye.

2. Fawell J., Bailey K., Chilton J., Dahi E., Fewtrell L., Magara Y. 2006. Fluoride in Drinking Water. IWA Publishing, London.

3. Blodgett D.W., Suruda A.J., Crouch B.I. 2001. Fatal Unintentional Occupational Poisonings by Hydrofluoric Acid in the U.S., American Journal of Industrial Medicine, 40 (2): 215-220.

4. Emsley J. 2011. Nature's Building Blocks: An A-Z Guide to the Elements (2nd ed.). Oxford University Press, Oxford.

5. Liteplo D.R., Gomes R., Howe P., Malcolm H. 2002. Fluorides-Environmental Health Criteria. 227: 1st draft., World Health Organization, Geneva.

6. McDonagh M.S., Whiting P.F., Wilson P.M., Sutton A.J., Chestnutt I., Cooper J., Misso K., Bradley M., Treasure E., Kleijnen J. 2000. Systematic Review of Water Fluoridation, British Medical Journal, 321 (7265): 855-859.

7. Hirzy B. 1999. Why Epa's Headquarters Union of Scientists Opposes Floridation, Floride, 32 (3): 179186.

8. Levy S.M. 1994. Review of Fluoride Exposures and Ingestion, Community Dent. Oral Epidemiol., 22: 173-175.

9. Türk Standartları Enstitüsü. Nisan 2005. Sular - İnsani Tüketim Amaçlı Sular. TS 266.

10. Sağlık Bakanlığı. 2006. İnsani Tüketim Amaçlı Sular Hakkında Yönetmelik. Resmi Gazete, Sayı: 26290, Tarih, 15.09.2006.

11. Küçükırmak G. 2007. Florun Fizyolojik Toksikolojik Karakteristikleri. Ege Üniversitesi, Tıp Fakültesi, Halk Sağlığı Anabilim Dalı, İzmir.

12. Kennedy D.C. 1999. Pan-Asia-Pasific Conference on Fluoride and Arsenic Research, Fluoride, 32 (4): 251-254.

13. Thermo Scientific. 2016. Fluoride Ion Selective Electrode User Guide. USA: Thermo Fisher Scientific, 16-17. 
14. Kahraman T., Alemdar S., Alişarlı M., Ağaoğlu, S. 2011. Fluoride Levels of Drinking Water in Bitlis Province (Turkey), Kafkas Univ. Vet. Fak. Derg., 17 (5): 825-829.

15. Eyde B. 1982. Determination of Fluoride in Plant Material with a Ione-selective Electrode, Fresenius Z. Anal. Chem., 311: 19-22.

16. Finkelman R., Centeno J., Selinus O. 2007. Medical Geology: The Emergene of a New Discipline, Terrae, 2 (1-2): 3-8.

17. Oruç N. 2005. Türkiye'de Yüksek Düzeyde Florür İçeren Kaynak Suları ve Sağlık Açısından Önemi, I. Tibbi Jeoloji Sempozyumu, pp48-51, 1-3 Aralık, Ankara.

18. Fidanc1 U.R., Sel T. 2001. The Industrial Fluorosis Caused by a Coal-burning Power Station and Its Effects on Sheep, Turk J. Vet. Anim. Sci., 25: 735-741.

19. Baysal A. 1999. Beslenme. 8. Bask1, Hatiboğlu, Ankara.

20. Bayşu N. 2008. Biyokimya. Güneş Tıp Kitapevleri, Ankara.

21. Aytuğ C.N., Alaçam E., Görgül S., Gökçen H., Tuncer S.D., Yılmaz K. 1991. Siğır Hastalıkları. Tüm. Vet. Hayv. Hiz. San. Tic. Ltd. Sti, Yayın No: 3, 457-460, İstanbul.

22. Han Y.Z., Zhang J.Q., Liu X.Y., Zhang L.Z., Yu X.H., Dai J.A. 1995. High Fluoride Content of Food and Endemic Fluorosis, Flouride, 24 (4): 201-202.

23. Maheshwari R.C. 2006. Fluoride in Drinking Water and Its Removal Meenakshi, J. Haz. Mat. B., 137: 456-463.

24. Tuluk B., Orhan F.K., Kaşali K. 2017. Erzurum İli Şebeke Sularının Fiziksel, Kimyasal ve Mikrobiyolojik Kaliteleri Üzerine Bir Araştırma, J. Turgut Ozal Med. Cent., 24 (1): 25-30.

25. Gültekin S., Sesal C., Kayhan F.E. 2016. İstanbul İli Anadolu Yakası Doğal Kaynak Sularının Kimyasal Analizlerinin Değerlendirilmesi, Marmara Fen Bil. Derg., 4: 132-140.

26. Atıcı A.A., Gültekin A., Şen F., Elp M. 2016. Erciş (Van) İlçesi İçme Sularının Su Kalitesi Özellikleri, YYÜ Tar. Bil. Derg., 26 (4): 517-528.

27. Yılmaz M., Kara İ.H., Poyraz B., Senih A. 2014. Mayda Konuralp Beldesinde İçme Sularının Elementer Analizi ve İçerdiği Ağır Metaller: Şebeke Suyu, Doğal Kaynak Suyu ve Zemzem Suyunun Karşılaştırılması, Konuralp Tıp Dergisi, 6 (3): 54-58.

28. Altınkale Demer S., Memiş Ü. 2011. Isparta İl Merkezinde İçme Sularının Farklı Florür İçeriklerinin İncelenmesi, Ekoloji, 20 (79): 77-82.

29. Blood D.C., Radostits O.M., Henderson J.A. 1983. Fluorine Poisoning. London: Veterinary Medicine, 1107-1111.

30. Schiffl H., Binswanger U. 1982. Renal Handling of Fluoride in Healthy Man, Renal Physiol., 5: 192196.

31. Krook L., Maylin G.A., Lillie J.H., Wallace R.S. 1983. Dental Fluorosis in Cattle, Cornell Vet., 73: 340-362.

32. Aras S., Tunç E.S., Saroglu I., Küçükesmen Ç. 2005. Florozis Tanısında Hasta Hikayesinin Önemi (vaka nedeniyle), A.Ü. Dis Hek. Fak. Der, 32 (1): 71-78.

33. Kaya S., Şanlı Y., Pirinçci İ., Yavuz H., Baydan E., Demet Ö., Bilgili A. 1995. Veteriner Klinik Toksikoloji. Ankara: Medisan Yayınevi, 80-85,.

34. Çenesiz S. 2003. Deneysel Kronik Flozis Oluşturulmuş Tuj Irkı Koyunlarda Eritrosit, SOD, CAT ve GSH-Px Aktivitelerinin Araştırılması. Kafkas Üniversitesi, Sağlık Bilimleri Enstitüsü, Doktora Tezi, Kars. 